\title{
COMPARISON OF THE PRODUCTION OF RECOMBINANT PROTEIN IN SUSPENSION CULTURE OF CHO CELLS IN SPINNER FLASK AND SHAKE FLASK SYSTEM
}

\author{
ZAINUl AbIDIN. S.N.Z AND ANUAR. N \\ Department of Chemical and Process Engineering, Faculty of Engineering, Universiti \\ Kebangsaan Malaysia, 43600 Bangi, Selangor. \\ zakiah.zainul@yahoo.com
}

\begin{abstract}
Chinese hamster ovary (CHO) cells is one of the most widely used production host for the commercial production of biopharmaceuticals product. They have been extensively studied and developed, and today provide a stable platform for producing monoclonal antibodies and recombinant proteins. This study focused on the production of recombinant protein in suspension culture of $\mathrm{CHO}$ cells in spinner flask and shake flask. The $\mathrm{CHO}$ cells were transfected with DNA plasmid containing lac Z gene which codes for $\beta$-galactosidase. The $\beta$-galactosidase-expressing $\mathrm{CHO}$ cells were adapted to suspension culture. The agitation speed for both spinner and shake flask were adjusted accordingly. The experiments were carried out in duplicate and samples were taken for cell count, determination of glucose consumption, lactate production and protein level by using biochemical assay. Results showed that cell growth in spinner flask is more favorable than in shake flask. The cell concentration in spinner flask is $58 \%$ higher than in shake flask. On the other hand, specific activity of $\beta$-galactosidase is $25 \%$ higher in spinner flask compared to shake flask, at the same agitation speed.
\end{abstract}

ABSTRAK: Sel ovari hamster China (Chinese hamster ovary (CHO)) digunakan secara meluas dalam hos pembiakan untuk tujuan komersil produk biofarmaseutikal. Ia telah dikaji dan dibangunkan secara ekstensif, dan kini ia menyediakan landasan yang stabil untuk penghasilan antibodi monoklon dan protein rekombinan. Kajian ini memfokuskan tentang penghasilan protein rekombinan menggunakan kultur ampaian sel $\mathrm{CHO}$ di dalam kelalang putar dan kelalang goncang. Sel $\mathrm{CHO}$ dimasukkan dengan plasmid DNA yang mengandungi gen lac $\mathrm{Z}$ yang juga memberikan kod untuk $\beta$-galaktosidase. Sel $\mathrm{CHO} \beta$ galaktosidase-terungkap dimasukkan ke dalam kultur ampaian. Kelajuan agitasi untuk kedua-dua kelalang putar dan kelalang goncang disesuaikan dengan sewajarnya. Eksperimen dijalankan menggunakan pendua dan sampel yang diambil untuk kiraan sel, penentuan penggunaan glukosa, penghasilan laktat dan aras protein dengan menggunakan cerakin biokimia. Keputusan menunjukkan tumbesaran sel di dalam kelalang putar lebih menggalakkan daripada dalam kelalang goncang. Kepekatan sel dalam kelalang putar adalah 58\% lebih tinggi daripada dalam kelalang goncang. Sebaliknya, pada kelajuan agitasi yang sama, aktiviti tertentu $\beta$-galaktosidase adalah $25 \%$ lebih tinggi dalam kelalang putar dibandingkan dengan kelalang goncang.

KEYWORDS: chinese hamster ovary; $\beta$-galactosidase; spinner flask; shake flask

\section{INTRODUCTION}

In recent years, the number of recombinant proteins used for therapeutic applications has increased dramatically and outstanding importance. These demands have driven the development of a variety of improvements in protein expression technology, generally 
concerning mammalian and microbial culture system. Therefore, the need for recombinant proteins in fundamental research and for clinical applications is continually increasing. Although other options are available, cultivated mammalian cells are often the primary choice for protein expression when functional protein folding and complex posttranslational modifications are required [1]. Complex proteins that are impossible for bacteria, yeast or insect cells to produce can be achieved by using mammalian cells [2]. Currently about $60 \%$ of all recombinant therapeutic proteins are produced in mammalian cells, mainly because of the ability of mammalian hosts to generate high-quality proteins that are similar in their biochemical properties to the naturally occurring human forms. This growing demand for high-quality recombinant therapeutics is driving the research and development of mammalian-cell-based manufacturing systems for enhanced production yields [3]. In industrial cell culture, Chinese Hamster Ovary (CHO) cells are commonly used as host for the production recombinant protein. They have been extensively studied and developed, and today provide a stable platforms for the production of recombinant therapeutic proteins and there are incentives to continuously improve the cell cultivation process [4].

$\mathrm{CHO}$ cells have become the standard mammalian host cells used in the production of recombinant proteins, although mouse myeloma (NS0), baby hamster kidney (BHK), human embryonic kidney (HEK-293) or human-retina-derived (PERC6) cells are alternatives. All these cell lines have been adapted to grow in suspension culture and are well suited for scale-up in stirred tank bioreactors. However, $\mathrm{CHO}$ cells are commonly employed as a host for producing various recombinant proteins for therapeutic applications [5].

The advantage of using $\mathrm{CHO}$ and NSO cells is that there are well-characterized platform technologies that allow for transfection, amplification and selection of highproducer clones [5]. However, $\mathrm{CHO}$ cells are mainly dominating the mass production of recombinant protein products because of their capabilities for single-cell suspension growth [6]. The development of a stable cell line is a costly and time-consuming process, and this investment may be lost if the recombinant protein is not approved for clinical use [4]. When considering a process scale-up for larger production, attention should be given to the productivity and the product quality $[5,6]$.

Classical cultivation apparatus at moderate scales is the glass spinner flask with a magnetically driven impeller for mixing. Spinner flasks are less expensive and easier to handle than glass or stainless steel bioreactors. Nevertheless, there is a considerable amount of work associated with their cleaning and sterilization [7]. Many suspensionadapted cell lines can achieve densities of 1 to $2 \times 10^{6}$ cells $\mathrm{ml}^{-1}$ or higher in these spinner flasks [5].

Fox (2003) stated that the major alternatives to spinner flask and bioreactors for culturing suspension mammalian cells are in suspension was agitated culture vessels such as Erlenmeyer flasks operated on orbital shaker. In most research, shake flask has been choose and used as the first method in fundamental studies as well as in developing a larger scale fermentation process. Shaken culture system are mostly developed for bacterial and fungal cultures, however applications for mammalian cell have also been reported since this system has been well established and proven to be very useful for initial culture experiments and screening purpose [9].

The purpose of the present work was to was to compare and to study the effectiveness of different cultivation vessels; spinner flasks and shake flasks for the growth and production of recombinant protein in Chinese hamster ovary (CHO) cell line. Such 
information will facilitate future optimization processes because mammalian cell have a highly individual character which will be highlighted by different glucose consumption, lactate production and sensitivity towards stress signal [8]. This study describes preliminary findings on the relationship between cell growth in agitated and shaker culture and production of $\beta$-galactosidase in $\mathrm{CHO}$ cells.

\section{MATERIALS AND METHODS}

\subsection{Cell Line and Medium}

The cell line used in this study was recombinant Chinese Hamster Ovary (CHO) cells [TF9(7)] obtained from Mammalian Cell Culture Laboratory of the National University of Malaysia (UKM). The cell line was transfected with a DNA fragment (plasmid) containing lac $\mathrm{Z}$ gene which codes for an expression of $\beta$-galactosidase [10]. The cells expressed $\beta$ galactosidase as the main protein product. CHO cells were grown in RPMI 1640 (Roswell Park Memorial Institute) media containing 5\% fetal bovine serum (Gibco) and 1\% penicillin streptomycin (Gibco). The cells were cells were maintained in T-flask and incubated at $37 \mathrm{C}$ and $5 \% \mathrm{CO}_{2}$.

\subsection{Culture condition}

Cultures were carried out in $500 \mathrm{ml}$ Wheaton spinner flask and Erlenmeyer flasks with working volume of $200 \mathrm{ml}$, at $37^{\circ} \mathrm{C}$ in a $5 \% \mathrm{CO}_{2}$ incubator. The stirring and agitation speeds were adjusted at $60,80,100$, and $120 \mathrm{rpm}$. The cell cultures were initiated at $2.5 \mathrm{x}$ $10^{5}$ cells $\mathrm{ml}^{-1}$ and were cultivated for 5 days.

The spinner flask used bulb-shape glass magnetic impeller (Wheaton) and the shake flask were shaken using incubator shaker (Heidolph). The screw cap of the flask was hand-tightened during incubation. $\mathrm{pH}$ were adjusted as necessary by adding sterile $\mathrm{NaOH}$ (1M) solution to raise the $\mathrm{pH}$ if the medium is acidic (yellow) or hydrochloric acid, $\mathrm{HCl}$ $(1 \mathrm{M})$ to reduce the $\mathrm{pH}$ if the medium is acidic (purple). All of the experiments were carried out in duplicate.

\subsection{Determination of Cells Growth and Production}

Samples $(2 \mathrm{ml})$ were taken daily for cell count and for the measurement of glucose, lactate and protein production.

\subsubsection{Measurement of Cell Concentration and Viability}

The cell viability was determined using the Trypan-blue dye exclusion method using 0.04\% trypan blue solution (Sigma). The cells were counted in a Fuchs Rosenthal haemocytometer counting chamber by using inverted microscope. Cell viability was expressed as the number of viable cells over the total number of cells.

\subsubsection{Glucose and Lactate Assays}

The sample were centrifuged at $1500 \mathrm{rpm}$ for $5 \mathrm{~min}$ and supernatant was analyzed for glucose and lactate concentrations by using biochemistry analyzer (YSI 2700 SELECT).

\subsubsection{MTT Assay}

Mitochondrial activity of the cells was determined using MTT (3-(4, 5dimethylyhiazolil-2)-2, 5-diphenyl tetrazolium bromide (Sigma) assay [11]. After cells were harvested, $100 \mu \mathrm{l}$ cells suspensions were loaded into 96 wells plates. Ten microliters of MTT ( $5 \mathrm{mg} \cdot \mathrm{ml}^{-1}$ ) was loaded to each well of the plates, and incubated for 3 hours. The absorbance was measured by using micro-plate reader (Versa Max) at $595 \mathrm{~nm}$. 


\subsubsection{Specific $\beta$-galactosidase Activity Assay}

Specific $\beta$-galactosidase activity assay was measured in cell lysates using the BetaRed $\beta$-galactosidase Assay kit (Novagene, USA) according to the manufacture's instructions. Samples were collected in tube and were spinned at $1500 \mathrm{rpm}$ for $5 \mathrm{~min}$. Then the cells were rinsed with PBS once and $100 \mu 1$ of Reportasol extraction buffer were added before respinned at $12000 \mathrm{rpm}$ for $5 \mathrm{~min}$. The supernatant was collected for $\beta$-galactosidase activity assay. According to the manufacture's protocol, 5-50 $\mu$ l cell extraction and negative control were placed in 96 well plates and $145 \mu$ l of BetaRed reaction buffer was added in each wells. The plates were incubated at $37^{\circ} \mathrm{C}$. BetaRed stop buffer was added to stop the reaction if the color changes to reddish. The results were measured at absorbance of $595 \mathrm{~nm}$. In order to measure the total amount of protein concentration, dye binding Quickstart Bradford protein assay (Bio-Rad, USA) was carried out according to manufacturer's protocol, by using bovine serum albumin (BSA, Sigma) as the standard (Bio-Rad). In brief, standard (125-2000 mg. $\mathrm{ml}^{-1}$ ) and lysate were incubated with working reagent at room temperature for at least 5 min. The absorbance was measured at $595 \mathrm{~nm}$ by using Bradford program on the Biophotometer.

\section{RESULTS AND DISCUSSION}

Cell growth and protein production were carried out in two different cultivation system; $500 \mathrm{ml}$ spinner flask and $500 \mathrm{ml}$ shake flask with working volume of $200 \mathrm{ml}$. The suspension cultures were started by filling $50 \%$ volume of the flasks with media to provide large headspace. This headspace was considered sufficient to supply oxygen to the cells, at least during the initial phases of growth, for $\mathrm{CHO}$ cells typically seeded at a density of $2 \times 10^{5}-3.5 \times 10^{5}$ cells $\mathrm{ml}^{-1}[12-14]$. In this experiment, the agitation speeds of the spinner flask were set at speed range of $60 \mathrm{rpm}$ to $120 \mathrm{rpm}$. From the observations it showed that this condition has prevented both settling of cells and foaming of the growth medium. The spinner flask feature a bulb-shape glass impeller that rotates from a fixed position at the center of the flask, which provides a slow and gentle orbital movement for the susupension culture.Mean while the shake flasks were shaken using an incubator shaker.

Results in Fig. 1(a) and (b), show the cell concentration and percentage of viable in spinner flask at different agitation speed. The maximum number of viable cells was obtained at $60 \mathrm{rpm}$. Cell density reached $1.84 \times 10^{6}$ cells ml $^{-1}$ with $99.7 \%$ viability after 72 hours. Whereas the lowest $\mathrm{t}$ cell concentration was achieved when culture was agitated at $100 \mathrm{rpm}$, with cell concentration and percentage viable cells $5.36 \times 10^{5} \mathrm{cells} \mathrm{ml}^{-1}$ and $79 \%$ respectively. This result showed that the cell concentration decrease as the agitation increased. The figures also showed that after 96 hours of cell cultivation, the cell growth rate has gradually has decreased until the end of the growth phase. Figure 1 (c) shows the correlation between viability of cells and cellular growth and proliferation by using MTT assay. Establishing a correlation between manual cell counts and metabolic kinetics was very challenging as the two types of measurement assess different aspects of physiological behavior of cultured cells [15]. It discovered that the cells viability was nearly similar with cellular growth. Evaluation of glucose consumption versus cell density indicated that in all experiments performed, cell growth was limited by this nutrient as shown in Fig. 1 (d). Cell stopped growing when glucose depleted in the medium. The rate of lactate production is directly related to the rate of glucose consumption. The relation between the serum concentration in cultivation medium and glucose production and lactate production rates is highly dependent on the cell line applied [16]. This suggests that the cell growth is limited to depletion of nutrients and accumulation of toxic metabolites. 
The value of highest glucose concentration was approximately 2.70 g. $\mathrm{L}^{-1}$ and gradually decreases with the minimum concentration 0.01 g. $\mathrm{L}^{-1}$. It shows that glucose consumption was consumed rapidly and was exhausted starting on day 2 , which gradually decline until day 5. Figure 1(e) shows lactate production and its accumulation and the final concentration achieved was $1.530 \mathrm{~g} / \mathrm{L}$. Glucose consumption and lactate accumulation correlated well with the cell growth parameters. Figure 1 (f) shows the value of specific activity $\beta$-galactosidase at different agitation speed. In spinner flask the best agitation speed was at $60 \mathrm{rpm}$ in which cells reached maximum viable cell concentration of $1.84 \mathrm{x}$ $10^{6}$ cells $\mathrm{ml}^{-1}$ after 72 hours with maximum specific activity $\beta$-galactosidase of 21.9 miliunit $\mathrm{mg}^{-1}$. At higher agitation speed, the value of specific $\beta$-galactosidase is lower than 1.0 milliunit $\mathrm{mg}^{-1}$. These results indicated that the amounts of specific activity of $\beta$ galactosidase produced at various agitation speeds were very much depended on the cell growth and agitation speed.
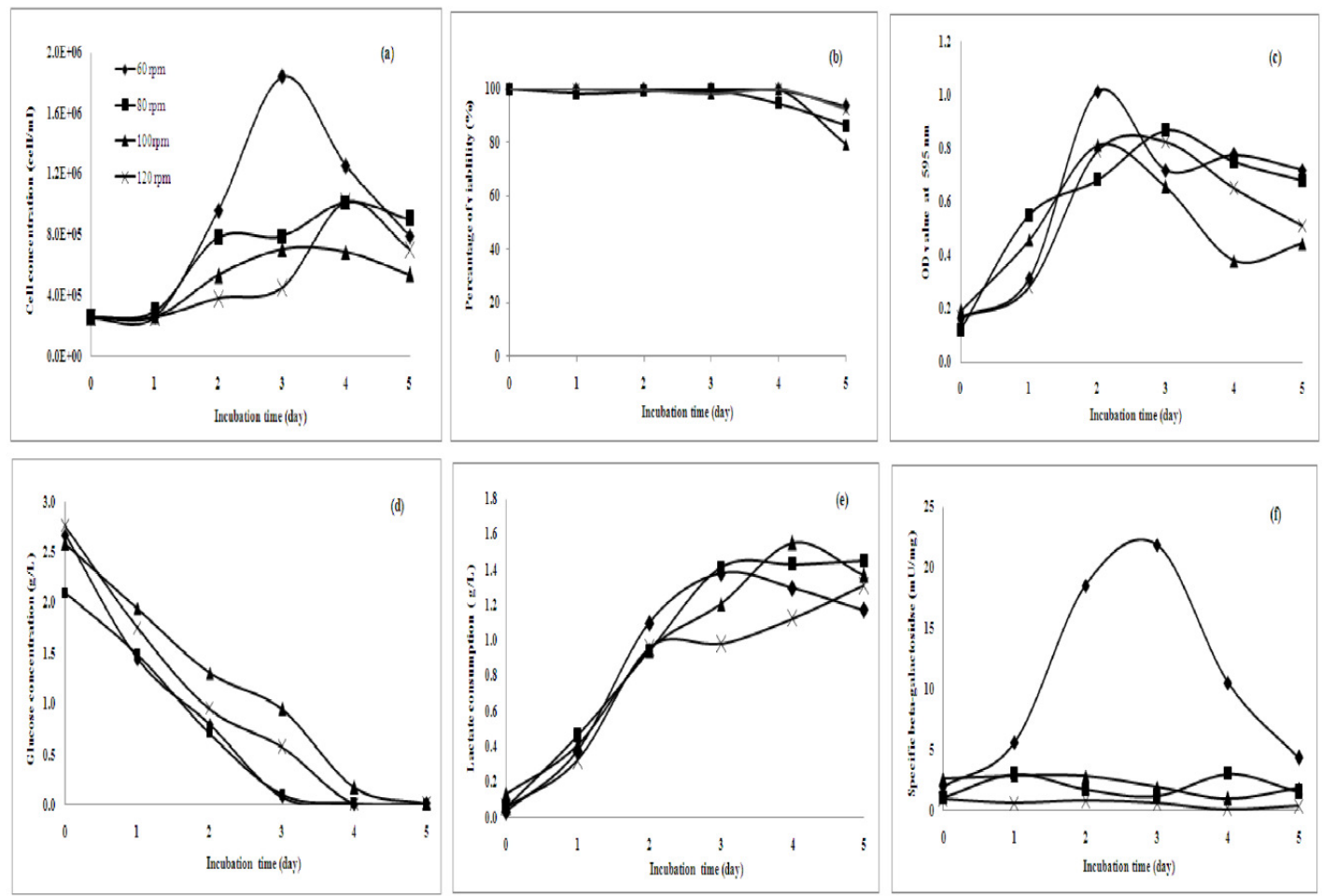

Fig. 1: Effect of different condition on the growth of recombinant $\mathrm{CHO}$ cells as shown by the (a) cell viability (b) percentage of cell viability, (c) Metabolic activity of cells (d) glucose consumption (e) lactate production (f) specific activity $\beta$-galactosidase in the culture media at different agitation speed in spinner flask.

In order to compare cells cultivation, by using shake flask, this experiment was carried out at the same rate of agitation speed of $60 \mathrm{rpm}$ to $120 \mathrm{rpm}$. $60 \mathrm{rpm}$ has been choose as minimum agitation because at lower revolutions the cell will settle at the bottom of the flask meanwhile at agitation speed above $120 \mathrm{rpm}$ agitation speed, the medium move too vigorously and cause cell death. From Fig. 2 (a), it shows that different cell concentrations were obtained in shake flask at different agitation speed. The maximum cell concentration was established at $100 \mathrm{rpm}$ with cell concentration of $1.07 \times 10^{6}$ cells $\mathrm{ml}^{-1}$. The result also showed that the cell viability started to decrease after 60 hours of cultivation. Percentage of viable cells shows that, agitation at $100 \mathrm{rpm}$ gave the best result 
for viability of cells, which show $99 \%$ cell viable. However, at $120 \mathrm{rpm}$ the cells viability started decreases in day 4 with only $25.5 \%$ viable cells. It shows that agitation speed of $120 \mathrm{rpm}$ is too vigorous for $200 \mathrm{ml}$ volume in Erlenmeyer flasks. At 60 and $80 \mathrm{rpm}$, the maximum value of total cells reached $7.24 \times 10^{5}$ cells $\mathrm{ml}^{-1}$ but viability started to decrease after 4 days of cultivation. Figure 2 (d) and (e) show glucose consumption and lactate production in shake flask at different agitation speeds, the data shows that glucose was consumed rapidly and started to decrease in day 2 and gradually declined until day 5 same as in spinner flask. Lactate production and accumulation reached final maximum concentrations of 1.565 g. $\mathrm{L}^{-1}$. Figure 2 (f) shows specific activity of $\beta$-galactosidase in shake flask, it shows stable protein production at $60 \mathrm{rpm}$, with maximum activity of 5.462 milliunit $\mathrm{mg}^{-1}$. It is less compare to protein production in spinner flask.
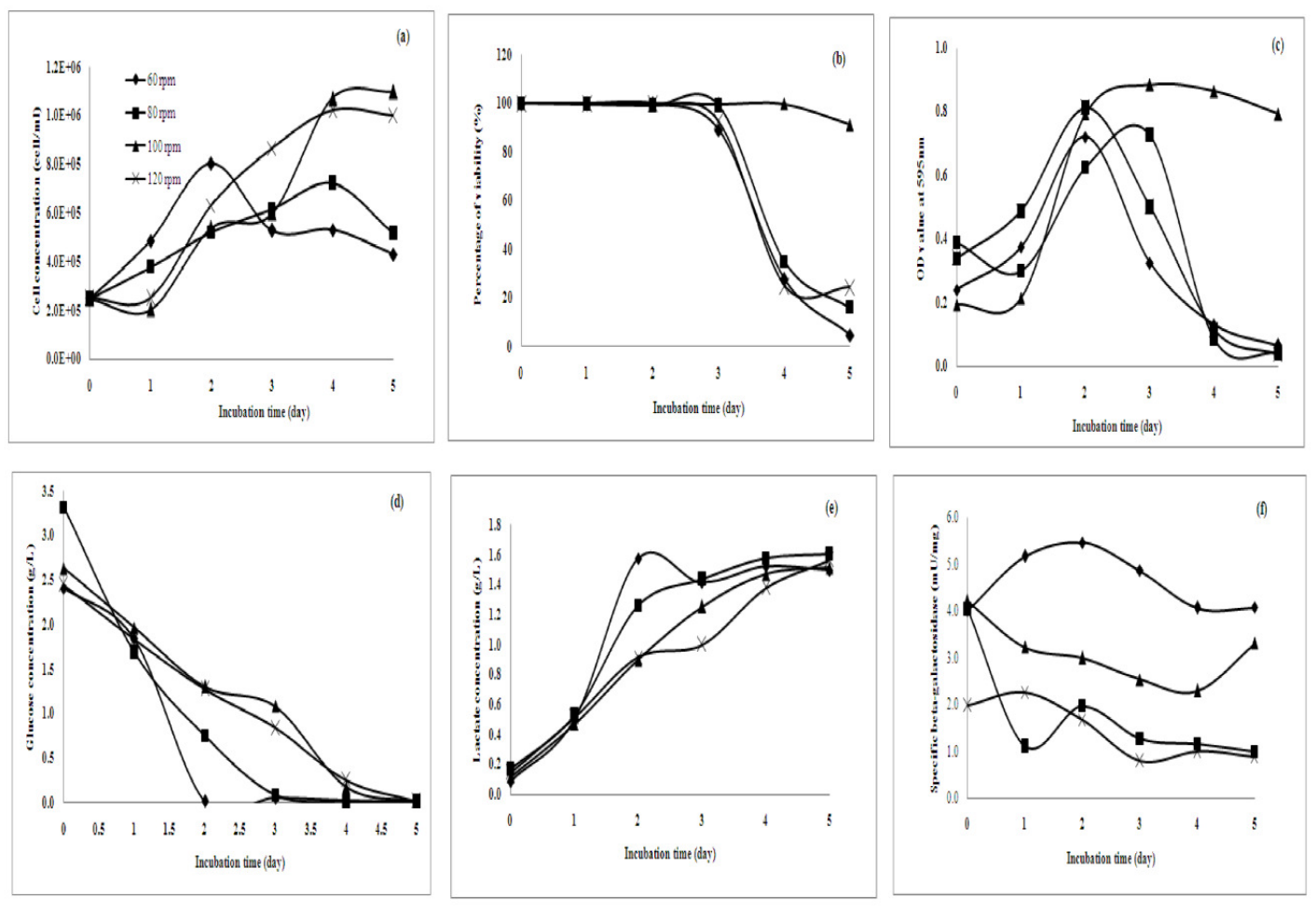

Fig. 2: Effect of different condition on the growth of recombinant $\mathrm{CHO}$ cells as shown by the (a) cell viability (b) percentage of cell viability, (c) metabolic activity if cells (d) glucose consumption (e) lactate production (f) specific activity $\beta$-galactosidase in the culture media at different agitation speed in shake flask.

\section{CONCLUSION}

The agitations provided by spinner flask give better cell growth and higher protein production when compared to shake flasks. This study showed that shake flask is not suitable for culturing CHO cells.. This might be due to high shear stress imposed in shake flask has affected the cell growth and viability. Culture in spinner flasks shows better cell growth and higher enzyme production with specific enxyme activity $\beta$-galactosidase of 21.917 milliunit $\mathrm{mg}^{-1}$ at $60 \mathrm{rpm}$, compare to shake flask with only 5.462 milliunit $\mathrm{mg}^{-1}$ at same agitation speed. 


\section{ACKNOWLEDGEMENT}

This study was supported by Research University Grant: UKM-GUP-NBT-08-26-095 from, Ministry of Science, Technology and Innovation, Malaysia.

\section{REFERENCES}

[1] Ryan. J.A., "Growing more cells: a simple guide to small volume cell culture scale-up," Corning Incorporated," 2004

[2] Woodside. S M. , Bowen B. D. \&. Piret. J. M., "Mammalian cell retention devices for stirred perfusion bioreactors". Cytotechnology," vol 28, pp. 163-175, 1998.

[3] Matasci. M,. Hacker. D. L, Baldi. L , Wurm. F. M., “. Recombinant therapeutic protein production in cultivated mammalian cells: current status and future prospects," Drug Discovery Today: Technologies, vol. 5, pp. 37-42, 2008.

[4] Girard P, Jordan M, Tsao M, Wurm FM., " Small-scale bioreactor system for process development and optimization," Biochemical Engineering, vol. 7, pp. 117-119, 2001.

[5] Schmidt, F.R., "Optimization and scale up of inductrial fermentation process, "Applied Microbiology and Biotechnology," vol. 68, pp. 425-435, 2005

[6] Wurm. F.M., "Production of recombinant protein therapeutics in cultivated mammalian cells," Nature Biotechnology, vol. 22, pp. 1393-1398, 2004.

[7] Ryan. J.A., "Growing more cells: a simple guide to small volume cell culture scale-up," Corning Incorporated," 2004.

[8] Fox. S.R, Patel. U.A, Yap.M. G.S., Wang. D.I C, “ Maximizing interferon - $\gamma$ production by Chinese Hamster Ovary cells through temperature shift optimization: experimental and modeling," Biotechnology and Bioengineering, vol. 85, pp. 177-184, 2003.

[9] Matasci. M,. Hacker. D. L, Baldi. L , Wurm. F. M., “. Recombinant therapeutic protein production in cultivated mammalian cells: current status and future prospects," Drug Discovery Today: Technologies, vol. 5, pp. 37-42, 2008.

[10] Saifudin. N. Ibrahim.N, Anuar. N., "Optimization in trasnfection and stable production of in Chinese Hamster Ovary Cells,” Biotechnology, vol 10(1), pp. 86-93, 2011

[11] Mosmann, T., "Rapid colorimetric assay for cellular growth and survival: application to proliferation and cytotoxicity assays," Journal of Immunological Methods, vol 65, pp. 55-63, 1983.

[12] Butler, M., "Animal cell cultures: recent achievements and perspectives in the production of biopharmaceuticals," Applied Microbiology and Biotechnology, vol. 68, pp. 283-291, 2005.

[13] Jayapal, K. P., Wlaschin, K. F., Hu, W. S., Yap, M. G. S., "Recombinant protein therapeutics from CHO cells-20 years and counting," Chem. Eng. Prog., vol. 103, pp. 40-47, 2007.

[14] Jesus. M.J.D and Wurm. FM., "Medium and process optimization for high yield, high density suspension cultures: from low throughput spinner flasks to high throughput milliliter," BioProcess International, vol. 7, pp. 12-17, 2009.

[15] Tsao, Y.S., Cardoso, A.G., Condon, G. G., Voloch, M., Lio, P., Lagos J.C., Kearns, B.G. \& Liu, Z., "Monitoring chinese hamster ovary cell culture by the analysis of glucose and lactate metabolism," Journal of Biotechnolog, vol 118, pp.316-327, 2005.

[16] Hesham, A. E., Abdeen, A., Abdeen, S., Elsayed, A. E., Demellawy, M. \& Shereef, A., "Serum concentration effects on the kinetics and metabolism of Hela-s3 cell growth and cell adaptability for successful proliferation in serum free medium," World Applied Sciences Journal. vol. 6 (5), pp.608-615, 2009. 